\title{
Method of Determining Relevance of Changing Processes of Condition Building Parameters
}

\author{
Andrey Volkov ${ }^{1, a}$, Pavel Chelyshkov ${ }^{1, b}$, Artem Sedov ${ }^{1, c}$, Denis Lysenko ${ }^{1, d}$ and \\ Anna Doroshenko ${ }^{1, e^{*}}$
}

${ }^{1}$ Moscow state university of civil engineering, 129337, Russia, Moscow, Yaroslavskoe shosse 26

arector@mgsu.ru, bchelyshkovpd@gmail.com, csedov.eit@gmail.com, denis.lysenko111@gmail.coml, ${ }^{\mathrm{e} p o c h t a . a v d @ g m a i l . c o m ~}$

*The corresponding author

Keywords: Intelligent building; Energy efficient technologies; The energy consumption; Intelligence buildings.

\begin{abstract}
In the modern world it is increasingly referred to the concept of intelligent building. Intelligent building referred to above all energy-efficient building, using alternative energy sources, as well as equipped with modern energy efficient technologies that reduce the energy consumption of the building in general. But for all the time and does not set forth a definition of intelligence buildings, which leads to different opinions and approaches to the understanding of the term.
\end{abstract}

\section{Introduction}

The original generic approach to the formal definition of the term "intelligence" of buildings in terms of abstract cybernetics involves the calculation of an abstract intelligence quotient and abstract building automation rate:

Abstract Intelligence quotient of buildings is determined by the following formula [1]:

$B I Q=\frac{Q\left(R_{1}\right)}{Q(R)}$

where $\mathrm{Q}$ - function of the considered set (measure of the set).

Abstract coefficient of buildings automation is determined by the following formula [2]:

$B A Q=\frac{Q\left(P_{2}\right)}{Q\left(P_{1}\right)}$

$\mathrm{P}$ - set of all change processes of parameters and their values of the building;

$\mathrm{P} 1$ - a subset of the change processes in values of the observed parameters of the building, $\mathrm{P} 1 \subset \mathrm{P}$;

$\mathrm{P} 2$ - a subset of managed processes change the values of the observed parameters of a building, $\mathrm{P} 2 \subset \mathrm{P} 1$;

$\mathrm{R}$ - set of management processes change of values the observed parameters of the building (the building process parameter control);

$\mathrm{R} 1$ - a subset of the change control process of values the observed parameters of the building (building parameters management processes), functional (F) adaptive own state space $\mathrm{X} 1, \mathrm{R} 1 \subset \mathrm{R}$.

$\mathrm{Q}$ - function of the sets under consideration [1].

The sets are calculated as shown in the formulas (3) - (6) [2].

$$
\begin{aligned}
& Q(R)=\sum_{r \in R} C_{r} \\
& Q\left(R_{1}\right)=\sum_{r \in R_{1}} C_{r} \\
& Q\left(P_{1}\right)=\sum_{r \in P_{1}} C_{r} \\
& Q\left(P_{2}\right)=\sum_{r \in P_{2}} C_{r}
\end{aligned}
$$

Quantifying the significance of changes in the process parameters for the processes of heat exchange in building is calculated according to the formula [7]: 


$$
C_{r}=\frac{E_{i}}{\sum_{i=1}^{n} E_{i}}
$$

Where Ei - energy capacity of the process adopted for the period

\section{Method}

There is a question of forming method of the unique determination of energy capacity of change processes of the values of building parameters.

Problem is to generate a set of expressions that define the energy capacity of the known types of processes for engineering systems.

As part of the work covered such types of buildings as:

- Residential apartment buildings

- $\quad$ Residential townhouses

- Public buildings

\section{Discussion}

Engineering systems have been considered in the work in accordance with the normative documents of the Russian Federation

Heating, ventilation and air conditioning, are considered in accordance with SNIP 41-01, water supply and sanitation systems are considered in accordance with SNIP 2.04.01 and SNIP 02.04.02, electric power systems are considered in accordance with the PUE.

Structurally proposed set of expression has the form shown in the table 1.

Table 1 . The structure of the expression of certain sets of processes energy capacity

\begin{tabular}{|c|c|c|c|}
\hline № & Engineering system & Type of engineering system & Expression \\
\hline 1 & \multirow{3}{*}{ Heating system } & Heaters radiator & $E=f_{1-1}$ \\
\hline 2 & & Convection & $E=f_{1-2}$ \\
\hline 3 & & Air heating & $E=f_{1-3}$ \\
\hline 4 & \multirow{5}{*}{ Ventilation system } & Natural ventilation system & $E=f_{2-1}$ \\
\hline 5 & & Forced ventilation system & $E=f_{2-2}$ \\
\hline 6 & & $\begin{array}{l}\text { Supply and exhaust ventilation } \\
\text { system }\end{array}$ & $E=f_{2-3}$ \\
\hline 7 & & $\begin{array}{l}\text { The system of supply and } \\
\text { exhaust ventilation with air } \\
\text { recirculation }\end{array}$ & $E=f_{2-4}$ \\
\hline 8 & & $\begin{array}{l}\text { The system of supply and } \\
\text { exhaust ventilation air } \\
\text { recuperation }\end{array}$ & $E=f_{2-5}$ \\
\hline 9 & \multirow{4}{*}{ The air conditioning system } & Air-cooling & $E=f_{3-1}$ \\
\hline 10 & & Air heating & $E=f_{3-2}$ \\
\hline 11 & & Air humidification by irrigation & $E=f_{3-3}$ \\
\hline 12 & & Air steam humidification & $E=f_{3-4}$ \\
\hline 13 & \multirow{2}{*}{ The water supply system } & Cold water supply & $E=f_{4-1}$ \\
\hline 14 & & Hot water supply & $E=f_{4-2}$ \\
\hline 15 & \multirow{2}{*}{ The sewerage system } & $\begin{array}{l}\text { Sewerage system without heat } \\
\text { recovery }\end{array}$ & $E=f_{5-1}$ \\
\hline 16 & & $\begin{array}{l}\text { Sewerage system with heat } \\
\text { recovery }\end{array}$ & $E=f_{5-2}$ \\
\hline 17 & Gas supply system & Gas supply system & $E=f_{6-1}$ \\
\hline
\end{tabular}


Using normative documents consider air heating by means of radiators (point 1 of Table 1 ). Where heating consists of two types: air-heating and heating walls.

Air-heating is defined by the formulas $(8-9)$.

$$
\begin{aligned}
& \mathrm{Q}_{\text {air }}=\mathrm{G}_{\text {air }} \mathrm{C}_{\text {air }} \rho_{\text {air }}\left(\mathrm{T}_{\text {out temp. }}-\mathrm{T}_{\text {in temp... }}\right)
\end{aligned}
$$

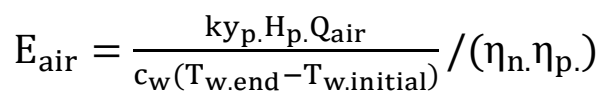

Where: $\mathrm{Q}_{\mathrm{air}}$ - thermal power required for heating the air in the radiator heating system, $\mathrm{W}$;

$\mathrm{G}_{\text {air }}$ - air consumption, $\frac{\mathrm{m}^{3}}{\mathrm{~s}}$;

$\mathrm{c}_{\text {air }}$ - specific heat of air, $\mathrm{J} /(\mathrm{kg} * 0 \mathrm{C})$;

$\rho_{\text {air }}$ - air density in $\mathrm{kg} / \mathrm{m} 3$;

$\mathrm{T}_{\text {out temp. }}$ - outdoor air temperature, $0 \mathrm{C}$;

$\mathrm{T}_{\text {in temp. }}$ - indoor air temperature, $0 \mathrm{C}$;

and $E_{\text {air }}-$ electric power needed to supply the coolant in the radiator heating system for heating the air, W;

$\mathrm{k}$ - the safety factor;

$\mathrm{y}-$ the proportion of the pumped liquid, $\mathrm{N} / \mathrm{m}^{3}$;

$\mathrm{H}_{\mathrm{p}}$ - the pump head, m;

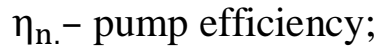

$\eta_{\mathrm{p}}-$ transfer coefficient;

$\mathrm{c}_{\mathrm{w}}$ - specific heat of water, $\mathrm{J} /(\mathrm{kg} * 0 \mathrm{C})$;

$\mathrm{T}_{\mathrm{w} . e n d}$ - end water temperature, $0 \mathrm{C}$;

$\mathrm{T}_{\mathrm{w} \text {.initial }}$ - initial water temperature, $0 \mathrm{C}$.

Heating walls is defined by the formulas $(10-11)$.

$\mathrm{Q}_{\mathrm{w}}=\mathrm{kF}\left(\mathrm{T}_{\text {in }}-\mathrm{T}_{\text {out }}\right)$

$\mathrm{E}_{\mathrm{w}}=\frac{\mathrm{k}_{\mathrm{s} . \mathrm{y}} \mathrm{H}_{\mathrm{p} . \mathrm{Q}_{\mathrm{w}}}}{\mathrm{c}_{\mathrm{w}}\left(\mathrm{T}_{\mathrm{w} . \text { end }}-\mathrm{T}_{\mathrm{w} \text {.initial. }}\right)} /\left(\eta_{\mathrm{n} .} \eta_{\mathrm{p} .}\right)$

$\mathrm{Q}_{\mathrm{w}}$ - thermal power required for heating the walls of the radiator heating system, $\mathrm{W}$;

$\mathrm{k}$ - heat transfer coefficient, $\mathrm{W} /\left(\mathrm{m}^{2} * 0 \mathrm{C}\right)$;

$\mathrm{F}$ - wall area, $\mathrm{m} 2$;

$\mathrm{T}_{\text {in }}$ - indoor air temperature, $0 \mathrm{C}$;

$\mathrm{T}_{\text {out }}$ - outdoor air temperature, $0 \mathrm{C}$;

$\mathrm{E}_{\mathrm{w}}$ - electric power needed to supply the coolant in the radiator heating system for heating the walls, $\mathrm{W}$;

$\mathrm{k}_{\mathrm{s}}$ - the safety factor;

$\mathrm{y}_{\text {п.в. }}$ - the proportion of the pumped liquid, $\mathrm{N} / \mathrm{m}^{3}$;

$\mathrm{H}_{\mathrm{p}}$ - the pump head, $\mathrm{m}$;

$\eta_{\mathrm{n}}$ - pump efficiency;

$\eta_{\mathrm{p}}$ - transfer coefficient;

$\mathrm{c}_{\mathrm{w}}$ - specific heat of water, $\mathrm{J} /\left(\mathrm{kg}^{*} 0 \mathrm{C}\right)$;

$\mathrm{T}_{\mathrm{w} . e n d}$ - end water temperature, $0 \mathrm{C}$;

$\mathrm{T}_{\mathrm{w} . \text { initial }}$ - initial water temperature, $0 \mathrm{C}$. 


\section{Conclusion}

The presence of such a set of expressions avoids subjective evaluations in determining significance of the individual processes change the value of the building parameters. The inclusion of the proposed set in the method of determining BIQ and BAQ allows an objective comparison of "intelligence" of different buildings and different types of buildings.

The prospect of work is the development of computer technology, realized in the automated calculation of the energy capacity and then quantify the significance of the processes of engineering systems. This computer technology will be the first step of the automated designing, implementing a formal approach to the definition of "intelligence" of buildings.

\section{Acknowledgements}

This work was financially supported by the Ministry of Russian Education (state task \#2014/107)

\section{References}

[1] A.A.Volkov, D.E. Namiot, M.A. Shneps-Shneppe, On the tasks of creating an effective infrastructure for habitat. // International journal of open information technologies. - 2013. - V7 (1). - pp. 1-10.

[2] J Duffy,W Beckman, Thermal processes using solar energy. - M .: Mir, 1977.

[3] M.M. Brodach, Heat Energy optimization orientation and size of the building. // Proceedings of the Research Institute for Building Physics. M., 1987. The heat treatment and durability of buildings.

[4] P.P.Denisov, Influence index space-planning solutions building on the heat consumption. "Housing" 1981, №1.

[5] B.I. Giyasov, The impact of infrastructure development on the urban living environment // Vestnik MGSU. - 2012 - V4

[6] Volk, R., Stengel, J., Schultmann, F. Building Information Modeling (BIM) for existing buildings - Literature review and future needs (2014) Automation in Construction, 38, pp. 109-127.

[7] Wang, X., Chong, H.-Y. Setting new trends of integrated Building Information Modelling (BIM) for construction industry (2015) Construction Innovation, 15 (1), pp. 2-6.

[8] Shanmuganathan, S. BIM - A global consultant's perspective (2013) Structural Engineer, 91 (11), pp. 102-104.

[9] Volkov, A. General information models of intelligent building control systems: Scientific problem and hypothesis (2014) Advanced Materials Research, 838-841, pp. 2969-2972.

[10] Volkov, A. General information models of intelligent building control systems: Basic concepts, determination and the reasoning (2014) Advanced Materials Research, 838-841, pp. 2973-2976.

[11] Volkov, A.A., Sedov, A.V., Chelyshkov, P.D. Modelling the thermal comfort of internal building spaces in social buildings (2014) Procedia Engineering, 91, pp. 362-367.

[12] Volkov, A., Chelyshkov, P., Sedov, A. Application of computer simulation to ensure comprehensive security of buildings (2013) Applied Mechanics and Materials, 409-410, pp. 1620-1623.

[13] Volkov, A., Sedov, A., Chelyshkov, P. Usage of building information modelling for evaluation of energy efficiency (2013) Applied Mechanics and Materials, 409-410, pp. 630-633. 